Int. J. Electrochem. Sci., 11 (2016) 2686 - 2708

\title{
Preparation and Evaluation of Nickel Oxide-Carbon Nanotube Supported Palladium as Anode Electrocatalyst for Formic Acid Fuel Cells
}

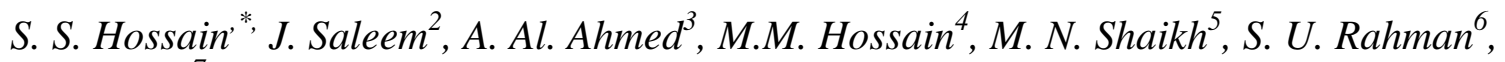 \\ G. $\mathrm{Mc} \mathrm{Kay}{ }^{7}$ \\ ${ }^{1}$ College of Engineering, King Faisal University, Hofuf-31982, Kingdom of Saudi Arabia \\ ${ }^{2}$ Department of Chemical Engineering, University of Karachi, Pakistan \\ ${ }^{3}$ CoRE Renewable Energy, ${ }^{4}$ Department of Chemical Engineering, and ${ }^{5} \mathrm{CENT}$, King Fahd University \\ of Petroleum \& Minerals, Dhahran 31261, Saudi Arabia \\ ${ }^{6}$ Midad Chemicals Company Limited, Al-Khobar, Saudi Arabia \\ ${ }^{7}$ Division of Sustainable Development, College of Science, Engineering and Technology, Hamad Bin \\ Khalifa University, Qatar Foundation, Doha, Qatar \\ *E-mail: snooruddin@kfu.edu.sa
}

doi: $10.20964 / 110402686$

Received: 19 October 2015 / Accepted: 22 December 2015 / Published: 1 March 2016

In this study, promotional effects of $\mathrm{NiO}$ on $\mathrm{Pd} / \mathrm{NiO}-\mathrm{CNT}$ catalysts (CNT: carbon nanotubes) for formic acid oxidation is investigated. Firstly, $\mathrm{NiO}$ is loaded on CNT in various amounts by precipitation-deposition method using urea as precipitating agent, and then palladium is deposited on the NiO-CNT support material by the borohydride reduction method. The synthesized catalysts are characterized by XRD, SEM-EDX, TEM, $\mathrm{N}_{2}$ adsorption-desorption and XPS for their morphology, composition and electronic structure. Cyclic voltammetry, chronoamperometry, and carbon monoxide stripping voltammetry reveal that the addition of $\mathrm{NiO}$ enhances the electrocatalytic activity and stability of Pd/NiO-CNT catalysts remarkably. Highest current density $\left(80.83 \mathrm{~mA} / \mathrm{cm}^{2}\right)$ is achieved for the catalyst with $15 \mathrm{wt}$. \% $\mathrm{NiO}$ content which is three times higher than the current density shown by $\mathrm{Pd} / \mathrm{CNT}\left(23.23 \mathrm{~mA} / \mathrm{cm}^{2}\right)$. The maximum power density in passive direct formic acid fuel cell is found to be 13.6 and $6.2 \mathrm{~mW} / \mathrm{cm}^{2}$ for $\mathrm{Pd} / 15 \% \mathrm{NiO}-\mathrm{CNT}$ and $\mathrm{Pd} / \mathrm{CNT}$, respectively, which clearly demonstrate the beneficial effect of addition of $\mathrm{NiO}$ on $\mathrm{Pd} / \mathrm{NiO}-\mathrm{CNT}$. The improvement in the electrocatalytic activity and stability is ascribed to the formation of small and highly dispersed $\mathrm{Pd}$ particles and the modification of electronic structure of $\mathrm{Pd}$ in presence of $\mathrm{NiO}$.

Keywords: Nickel oxide; Carbon nanotubes; Palladium-electrocatalyst; Passive formic acid fuel cell 


\section{FULL TEXT}

(C) 2016 The Authors. Published by ESG (www.electrochemsci.org). This article is an open access article distributed under the terms and conditions of the Creative Commons Attribution license (http://creativecommons.org/licenses/by/4.0/). 